\title{
Kemampuan Menentukan Jenis dan Batasan Informasi Mahasiswa Semester III Program Studi Pendidikan Biologi FKIP Universitas Muhammadiyah Surakarta (Studi Kasus pada Matakuliah Sistematika Invertebrata T.A 2014/2015)
}

\author{
PUTRI AGUSTINA ${ }^{1 *}$, ALANINDRA SAPUTRA ${ }^{2}$ \\ ${ }^{1}$ Prodi Pendidikan Biologi FKIP Universitas Muhammadiyah Surakarta \\ Jl. A. Yani Tromol Pos 1, Pabelan Kartasura, Surakarta, Jawa Tengah 57102 \\ ${ }^{2}$ Prodi Pendidikan Biologi FKIP Universitas Sebelas Maret \\ Jl. Ir Sutami 36 A, Surakarta, 57126, Indonesia \\ *email: pa182@ums.ac.id
}

Manuscript received: 15 Desember 2014 Revision accepted: 25 Januari 2015

\begin{abstract}
Penelitian ini bertujuan untuk mengetahui gambaran kemampuan mahasiswa semester III prodi pendidikan Biologi FKIP Universitas Muhammadiyah Surakarta tahun ajaran 2014/2015 dalam menentukan jenis dan batasan informasi pada matakuliah Sistematika Invertebrata. Kemampuan menentukan jenis dan batasan in-formasi merupakan standar pertama literasi informasi yang dikeluarkan oleh Association of College and Re-search (ACRL). Penelitian ini merupakan penelitian deskriptif. Populasi penelitian adalah mahasiswa prodi Pendidikan Biologi FKIP UMS semester III yang berjumlah 167 orang dari 5 kelas paralel. Sampel diambil secara acak (random sampling) menjadi 78 orang dari 2 kelas paralel yaitu B dan D. Teknik pengumpulan data dilakukan dengan pengamatan (observasi), kuesioner, serta studi kepustakaan dan dokumen. Hasil pe-nelitian menunjukkan bahwa: 94.9\% mahasiswa telah mampu menentukan langkah yang dilakukan dalam mencari informasi; mahasiswa telah mampu memilih bentuk-bentuk informasi yang dapat digunakan seba-gai sumber referensi baik informasi tercetak (39.7\%), digital/elektronik (17.9\%), maupun keduanya $(42.3 \%)$ serta pada umumnya masih jarang menentukan batasan informasi $(84.6 \%)$ hanya sesuai dengan topik batas-an dan masih jarang mengevaluasi batasan informasi yang telah dibuat $(58.6 \%)$.
\end{abstract}

Keywords: standar literasi informasi, menentukan jenis dan batasan informasi, ACRL

\section{LATAR BELAKANG}

Matakuliah Sistematika Invertebrata (SI) merupakan matakuliah wajib bagi maha-siswa program studi Pendidikan Biologi FKIP UMS semester 3. Secara umum ma-takuliah SHI mempelajari tentang dasar-dasar klasifikasi, taksonomi, binomial no-menclature, serta ciriciri umum dan khusus (morfologi, fisiologi, dan embriologi) he-wan Invertebrata mulai dari tingkatan takson phylum, classis, ordo, familia, genus, dan spesies. Matakuliah ini membahas mu-lai dari phylum Protozoa (hewan bersel sa-tu) sampai Echinodermata (hewan berkulit duri). Sistematika hewan diartikan sebagai ilmu yang secara ilmiah mempelajari ten-tang keanekaragaman hewan serta sejarah hubungan kekerabatan evolusi yang ada di-antara berbagai kelompok hewan. Sistema-tika hewan merupakan gabungan antara taksonomi dan filogenetik (Perwati, 2010). Sistematika invertebrata khususnya tentang taksonomi sudah mulai intensif dipelajari dan dikembangkan mulai tahun 1700-an. Perkembangan taksonomi mulai dari awal sampai sekarang selalu dipengaruhi oleh perkembangan ilmu pengetahuan dan tek-nologi yang ada. Oleh karena itu, taksono-mi mengalami perkembangan yang sangat pesat dan selalu mengalami perkembangan dan penyempurnaan.
Berdasarkan karakteristik kajian dari matakuliah SI, maka mahasiswa dituntut untuk selalu peka terhadap perubahan sis-tem klasifikasi Invertebrata sesuai dengan perkembangan pengetahuan yang ada. Sa-lah satu cara agar mahasiswa dapat meng-ikuti perkembangan kajian matakuliah SHI adalah dengan mengakses berbagai informasi dari berbagai sumber tentang perkem-bangan taksonomi hewan. Dengan mem-baca dan mengikuti perkembangan terkini taksonomi hewan khususnya Invertebrata, maka diharapkan mahasiswa memiliki pengetahuan yang luas tentang matakuliah ini sehingga harapannya hasil belajar maha-siswa akan meningkat.

Mahasiswa dalam proses pembelajaran merupakan pengguna informasi yang ber-ada di lingkungan akademik. Kebutuhan in-formasi mahasiswa berbeda dengan profesi atau pengguna informasi lainnya. Mahasiswa dituntut untuk memiliki kemampuan mengolah pengetahuan yang sudah dimiliki dan memanfaatkan pengetahuannya agar in-formasi itu tidak hanya bermanfaat untuk masa sekarang tetapi bermanfaat juga untuk kehidupannya di kemudian hari. Mahasiswa juga dituntut untuk lebih mandiri dalam melaksanakan proses pembelajaran dan me-nyelesaikan tugasnya.

Mahasiswa yang mengikuti matakuliah SHI adalah mahasiswa prodi P. Biologi FKIP UMS angkatan 2013. Sebelum mengikuti perkuliahan SI, pada semester genap 
tahun ajaran 2013/2014 mahasiswa telah memperoleh beberapa matakuliah diantaranya adalah Keanekaragaman Hayati dan Biokimia. Berdasarkan pengalaman mengampu matakuliah sebelumnya, diketahui bahwa kemauan membaca dan menggali informasi mahasiswa masih sangat rendah. Mahasiswa cenderung menyukai proses perkuliahan dengan sistem ceramah atau transfer materi dari dosen kepada mahasiswa. Akibatnya, retensi mahasiswa terhadap konsep-konsep yang telah dipelajari menjadi rendah. Hal ini terlihat dari hasil ujian akhir matakuliah Keanekaragam-an Hayati dan Biokimia. Hasil akhir mata-kuliah Prakikum Biokimia menunjukkan 15\% mahasiswa memperoleh nilai $\mathrm{A}, 15 \%$ nilai $\mathrm{AB}, 25 \%$ nilai $\mathrm{B}, 40 \%$ nilai $\mathrm{BC}$, dan $5 \%$ nilai $\mathrm{C}$ sedangkan hasil yang ditarget-kan adalah minimal $40 \%$ mahasiswa memperoleh nilai B.

Selain itu, hasil analisis laporan dan tugas-tugas pada matakuliah sebelumnya me-nunjukkan bahwa kemampuan mahasiswa dalam menggali informasi melalui referensi baik dari jurnal ilmiah, buku teks, atau sumber informasi yang lain masih sangat rendah. Hal ini dibuktikan dengan beberapa tugas yang diberikan, referensi yang dipilih sebagian besar diambil dari blog pribadi yang tidak dapat dipertanggungjawabkan secara ilmiah. Hal ini menunjukkan bahwa kemampuan mahasiswa dalam menentukan jenis dan batasan informasi yang diperlukan masih kurang. Kemampuan menentukan jenis dan batasan informasi yang diperlukan menurut ACRL (2000) dan Reza (2013) merupakan standar pertama dari literasi informasi.

Penguasaan literasi informasi dipandang sangat penting dalam proses pembelajaran sehingga menjadi bagian tak terpisahkan dari program pendidikan, mulai dari jenjang pendidikan dasar sampai dengan pendidikan tinggi. Terutama bagi institusi pendidikan tinggi yang sudah menerapkan Kuriku-lum Berbasis Kompetensi (KBK), penguasaan literasi informasi menjadi kompetensi yang penting untuk dimiliki setiap mahasis-wa (Iman, 2013).

Literasi menurut Resmini (2012) secara luas dimaknai sebagai kemampuan berbahasa yang mencakup kemampuan menyimak, berbicara, membaca, dan menulis, ser-ta kemampuan berpikir yang menjadi elemen di dalamnya. Sedangkan literasi menurut UNESCO (2006) berarti "familiar deng-an literatur". Seseorang disebut literate apa-bila memiliki pengetahuan yang hakiki un-tuk digunakan dalam setiap aktivitas yang menuntut fungsi literasi secara efektif da-lam masyarakat dan pengetahuan yang di-capainya dengan membaca, menulis, dan arithmetic memungkinkan untuk dimanfaat-kan bagi dirinya sendiri dan masyarakat.

Literasi informasi menurut Kuhlthau, et al. (2007) merupakan kemampuan yang diperlukan seseorang untuk mengakses dan menggunakan berbagai sumber informasi dengan efektif dan efisien. Literasi infor-masi menurut Nasution (2010) diartikan sebagai kemampuan dalam menemukan in-formasi yang dibutuhkan, termasuk pemahaman bagaimana bahan pustaka diatur, a-krab dengan sumber yang tersedia (terma-suk format informasi dan alat penelusuran otomatis) dan ilmu pengetahuan dari teknik yang digunakan. Konsep literasi informasi mencakup kemampuan untuk mengevaluasi isi informasi dengan kritis dan mengguna-kannya secara efektif, seperti pemahaman terhadap perangkat teknologi sebagai dasar penyampaian informasi dalam berbagai bidang.

Standar pertama literasi informasi menu-rut AESL dan AECT (1988) yaitu menentukan jenis dan batasan informasi yang diperlukan. Standar ini memiliki empat indikator yaitu: (1) mendefinisikan dan menyatakan dengan jelas kebutuhannya terhadap informasi; (2) mengidentifikasi berbagai jenis dan bentuk dari sumber informasi yang potensial; (3) mempertimbangkan biaya dan keuntungan yang diperoleh dari informasi yang dibutuhkan; serta (4) mengevaluasi jenis dan batas informasi yang diperlukan.

Penelitian ini bertujuan untuk mengetahui gambaran kemampuan menentukan jenis dan batasan informasi mahasiswa se-mester III prodi pendidikan Biologi FKIP UMS tahun ajaran 2014/2015 pada mata-kuliah Sistematika Invertebrata.

\section{METODE}

\section{Jenis Penelitian}

Penelitian ini merupakan jenis penelitian deskriptif. Penelitian deskriptif menurut Su-giyono (2006) merupakan penelitian yang dilakukan untuk mengetahui nilai variabel mandiri, baik satu variabel atau lebih (independen) tanpa membandingkan atau meng-hubungkan dengan variabel lainnya. Pada penelitian ini, hanya dipaparkan data yang diperoleh dari responden (mahasiswa) me-lalui kuesioner untuk selanjutnya diinterpretasikan.

\section{Waktu dan Tempat Penelitian}

Penelitian ini dilaksanakan di Program Studi Pendidikan Biologi FKIP UMS yang berlokasi di Jl. Ahmad Yani Tromol Pos 1 Pabelan Kartasura Surakarta. Penelitian dilaksanakan pada bulan November 2014 sam pai Januari 2015.

\section{Populasi dan Sampel}

Populasi menurut Sugiyono (2006) me-rupakan wilayah generalisasi yang terdiri dari obyek/subyek yang mempunyai kualitas dan karakteristik tertentu yang ditetap-kan oleh peneliti untuk dipelajari dan ke-mudian ditarik kesimpulannya. Sedangkan sampel merupakan bagian dari jumlah dan karakteristik yang dimiliki oleh populasi.

Populasi pada penelitian ini adalah ma-hasiswa Program Studi Pendidikan Biologi FKIP Universitas Muhammadiyah Surakarta semester III Tahun Ajaran 2014/2015 yang mengambil matakuliah Sistematika Invertebrata (SI) yang terdiri dari 5 kelas paralel dengan total jumlah 167 mahasiswa. Sampel pada penelitian ini diambil secara acak (random sampling). Mahasiswa yang dijadikan sebagai responden adalah mahasiswa dari kelas 
paralel B dan D Program Studi Pendidikan Biologi FKIP UMS yang berjumlah 78 mahasiswa.

\section{Teknik Pengumpulan Data}

Teknik yang digunakan dalam pengumpulan data penelitian ini antara lain:

1. Pengamatan (observasi), yaitu mengadakan pengamatan awal terhadap mahasis-wa semester III Prodi Pendidikan Biolo-gi yang menempuh matakuliah SI.

2. Kuesioner, yaitu pengumpulan data dengan memberikan daftar pertanyaan atau angket untuk diisi oleh responden.

3. Studi kepustakaan dan dokumen melalui buku, jurnal, dan dokumen lain yang ber kaitan dengan masalah yang diteliti.

\section{Jenis dan Sumber Data}

Data penelitian ini merupakan data kua-litatif yang berupa deskripsi kemampuan menentukan jenis dan batasan informasi mahasiswa semester III prodi pendidikan Biologi pada matakuliah SI. Data penelitian diperoleh secara langsung dari responden melalui kuesioner.

\section{Instrumen Penelitian}

Instrumen penelitian yang digunakan pada penelitian ini adalah kuesioner (angket). Menurut Sugiyono (2006), kuesioner merupakan sejumlah pertanyaan tertulis yang digunakan untuk memperoleh informasi atau data dari responden. Kuesioner pada penelitian ini disusun dalam bentuk pertanyaan. Kuesioner dibuat berdasarkan indikator kemampuan menentukan jenis dan batasan informasi menurut ACRL (2000) dan dimodifikasi berdasarkan Nasution (2009).

\section{Analisis Penelitian}

Data yang diperoleh dari hasil kuesioner dianalisis dengan metode deskriptif. Data di tabulasi dengan menyusun ke dalam tabel sistematis kemudian dihitung persentasenya untuk selanjutnya dianalisis dan diinterpre-tasikan. Analisis data dihitung menggunakan rumus sebagai berikut:

$$
\mathrm{P}=\mathrm{F} / \mathrm{n}
$$

Keterangan:

$\mathrm{P}=$ persentase

$\mathrm{F}=$ jumlah jawaban yang diperoleh

$\mathrm{n}=$ jumlah responden

Untuk menafsirkan besarnya persentase yang diperoleh dari tabulasi data, digunakan metode menurut Supardi (1979) yaitu:

$1-25 \%$ : sebagian kecil

$26-49 \%$ : hampir setengah

$50 \%$ : setengah

$51-75 \%$ : sebagian besar

$76-99 \%$ : pada umumnya

$100 \%$ : seluruhnya

\section{HASIL DAN PEMBAHASAN}

\section{Hasil Penelitian}

Penelitian ini bertujuan untuk mengeta-hui profil kemampuan mahasiswa dalam menentukan jenis dan batasan informasi yang diperlukan. Kemampuan menentukan jenis dan batasan informasi merupakan standar pertama dari literasi informasi.

Kemampan mahasiswa untuk menentu-kan jenis dan batasan informasi diperoleh dari hasil isian kuesioner literasi informasi untuk aspek pertama yang rekapitulasinya dapat disajikan pada Tabel 1.

Tabel 1. Persentase kemampuan menentukan jenis dan batasan informasi

\begin{tabular}{|c|c|c|c|}
\hline No & Kategori Jawaban & $f$ & $\%$ \\
\hline \multirow[t]{5}{*}{1} & $\begin{array}{l}\text { Merumuskan langkah memperoleh } \\
\text { informasi }\end{array}$ & 4 & 5.13 \\
\hline & Meminta bantuan pada pihak lain & 0 & 0.00 \\
\hline & $\begin{array}{l}\text { Tidak melakukan apapun hingga ada } \\
\text { yang membantu }\end{array}$ & 0 & 0.00 \\
\hline & $\begin{array}{l}\text { Merumuskan apa yang ingin dicari } \\
\text { dan menentukan strategi memperoleh } \\
\text { informasi }\end{array}$ & 74 & 94.9 \\
\hline & Jumlah Total & 78 & 100 \\
\hline \multirow[t]{5}{*}{2} & $\begin{array}{l}\text { Informasi tercetak (buku, jurnal, } \\
\text { leaflet, dsb) }\end{array}$ & 31 & 39.7 \\
\hline & $\begin{array}{l}\text { Digital/elektronik (website ilmiah, } \\
\text { jurnal online) }\end{array}$ & 14 & 17.9 \\
\hline & Audio visual & 0 & 0.00 \\
\hline & Bentuk a, b, dan c & 33 & 42.3 \\
\hline & Jumlah Total & 78 & 100 \\
\hline \multirow[t]{5}{*}{3} & Selalu & 1 & 1.28 \\
\hline & Sering & 0 & 0.00 \\
\hline & Kadang-kadang & 66 & 84.6 \\
\hline & Tidak pernah & 11 & 14.1 \\
\hline & Jumlah Total & 78 & 100 \\
\hline \multirow[t]{5}{*}{4} & Selalu & 19 & 24.4 \\
\hline & Sering & 13 & 16.7 \\
\hline & Kadang-kadang & 46 & 58.9 \\
\hline & Tidak pernah & 0 & 0.00 \\
\hline & Jumlah Total & 78 & 100 \\
\hline \multirow[t]{5}{*}{5} & $\begin{array}{l}\text { Pembahasan setiap Phylum hewan } \\
\text { Invertebrata }\end{array}$ & 2 & 2.56 \\
\hline & $\begin{array}{l}\text { Pembahasan mendalam mengenai } \\
\text { klasifikasi pada setiap Phylum }\end{array}$ & 3 & 3.85 \\
\hline & $\begin{array}{l}\text { Karakteristik, klasifikasi, dan peranan } \\
\text { setiap Phylum hewan Invertebrata }\end{array}$ & 61 & 78.2 \\
\hline & $\begin{array}{l}\text { Semua hal yang berhubungan dengan } \\
\text { hewan Invertebrata }\end{array}$ & 12 & 15.4 \\
\hline & Jumlah Total & 78 & 100 \\
\hline
\end{tabular}

\section{Pembahasan}

Hasil analisis persentase jawaban res-ponden (mahasiswa) untuk aspek kemam-puan menentukan jenis dan batasan infor-masi yang diungkapkan pada Tabel 1 me-nunjukkan bahwa sebagian besar mahasis-wa telah memiliki kemampuan menentukan jenis dan batasan informasi yang diperlu-kan. Kemampuan menentukan jenis dan batas informasi yang diperlukan merupakan standar pertama 
literasi informasi yang ter-cantum dalam Standar Literasi Informasi untuk Pendidikan Tinggi (ACRL, 2000). Kemampuan menentukan jenis dan batasan informasi menurut standar tersebut memili-ki empat indikator yaitu: (1) mendefinisikan dan menyatakan dengan jelas kebutuhan terhadap informasi; (2) mengidentifikasi berbagai jenis dan bentuk dari sumber in-formasi yang potensial; (3) mempertim-bangkan biaya dan keuntungan yang diper-oleh dari informasi yang dibutuhkan; serta (4) mengevaluasi jenis dan batas informasi yang diperlukan.

Berdasarkan hasil analisis persentase ja-waban responden terhadap pertanyaan no-mor satu yaitu "ketika mencari informasi, apa hal pertama yang Anda lakukan" seperti ditunjukkan pada Tabel 1 diketahui bahwa pada umumnya mahasiswa (94.9\%) telah memahami hal yang harus dilakukan ketika mencari informasi yaitu merumuskan apa yang ingin dicari dan menentukan strategi memperoleh informasi. Sedangkan hanya sebagian kecil (5.13\%) yang menjawab me-rumuskan langkah memperoleh informasi. Hal pertama yang dilakukan ketika mencari informasi adalah menentukan apa yang ingin dicari dan setelah dilakukan penca-tatan terhadap hal-hal yang akan dicari ke-mudian dilanjutkan dengan menentukan ba-gaimana cara untuk memperoleh informasi tentang hal-hal tersebut. Strategi memper-oleh informasi mungkin dapat berbeda an-tara hal yang satu dengan yang lain. Hasu-gian (2006) menyatakan bahwa strategi memperoleh informasi merupakan suatu proses untuk memperoleh informasi yang benar-benar relevan dengan kebutuhan in-formasi. Strategi pencarian informasi meru-pakan himpunan keputusan dan tindakan yang dilakukan dalam proses pencarian de-ngan tujuan untuk menemukan sejumlah in-formasi yang relevan. Kemampuan maha-siswa dalam merumuskan apa yang ingin dicari merupakan wujud dari kemampuan mendefinisikan dan menyatakan dengan je-las kebutuhannya terhadap informasi. AC-RL (2000) menyatakan bahwa kemampuan ini dapat dilihat dari kemauan mahasiswa untuk berpartisipasi dalam diskusi kelas, bergabung dengan kelompok kerja ataupun berdiskusi melalui alat elek-tronik untuk menentukan kebutuhan informasinya de-ngan cara merumuskan pertanyaan dasar dari kebutuhan informasinya, mendalami sumber informasi untuk meningkatkan ke-dekatan dengan topik yang sedang dicari, mendefinisikan kebutuhan informasi dan dilanjutkan dengan mengidentifikasi kata kunci dari istilah yang mendeskripsikan ke-butuhan informasi.

Tabel 1 menunjukkan bahwa hasil ana-lisis persentase jawaban responden untuk pertanyaan nomor dua "apabila Anda men-cari informasi, mana bentuk informasi yang akan Anda pilih" yaitu 39.7\% mahasiswa memilih bentuk informasi tercetak (buku, jurnal, leaflet, dan lain sebagainya) dan $42.3 \%$ memilih bentuk informasi tercetak, digital atau elektronik, dan audio visual. Sedangkan sebagian kecil mahasiswa (17.9\%) memilih hanya bentuk informasi digital/ elektronik. Bentuk informasi yang diberi-kan pada pilihan jawaban tersebut pada dasarnya merupakan alat/sumber informasi yang membantu dalam memenuhi kebutuh-an informasi. Prasetyawan (2011) meng-ungkapkan beberapa sumber informasi dan jenis informasi yang dihasilkan seperti pada Tabel 2.

Tabel 2. Sumber Informasi dan Jenis Infor-masi yang Dihasilkan

\begin{tabular}{|c|c|}
\hline Alat/Sumber & Jenis informasi yang dihasilkan \\
\hline Katalog perpustakaan & $\begin{array}{l}\text { Koleksi bahan pustaka: buku, } \\
\text { terbitan berkala, laporan, hasil } \\
\text { konferensi, koleksi audio-visual }\end{array}$ \\
\hline Bibliografi buku & $\begin{array}{l}\text { Buku, laporan, prosiding, dan } \\
\text { terbitan monografi lainnya }\end{array}$ \\
\hline $\begin{array}{l}\text { Abstrak dan indeks } \\
\text { jurnal }\end{array}$ & $\begin{array}{l}\text { Artikel jurnal, laporan, paper } \\
\text { konferensi, beberapa buku }\end{array}$ \\
\hline Current Awareness & Artikel jurnal, terbitan berkala \\
\hline Services & lainnya \\
\hline Indeks khusus & $\begin{array}{l}\text { Laporan, hasil konferensi, thesis, } \\
\text { paten, standard, publikasi yang } \\
\text { diterbitkan lembaga tertentu }\end{array}$ \\
\hline Institusi dan orang & Hampir semua jenis informasi \\
\hline $\begin{array}{l}\text { CD-ROM dan Media } \\
\text { Rekam Lainnya }\end{array}$ & Hampir semua jenis informasi \\
\hline Internet/online database & $\begin{array}{l}\text { Berbagai bentuk karya digital } \\
\text { seperti } e \text {-journal, } e \text {-book, } e- \\
\text { articles, dan sebagainya }\end{array}$ \\
\hline
\end{tabular}

Pertanyaan nomor tiga "apakah Anda menentukan batasan (hanya sesuai topik bahasan) untuk informasi yang Anda cari?" berdasarkan hasil pada Tabel 1 menunjuk-kan bahwa pada umumnya (84.6\%) maha-siswa kadang-kadang menentukan batasan untuk informasi yang dicari. Sedangkan sebagian kecil lainnya (14.1\%) tidak pernah menentukan batasan untuk informasi yang dicari dan $1.28 \%$ selalu menentukan batas-an untuk informasi yang dicari. Batasan informasi perlu dilakukan untuk menghin-dari informasi yang kurang atau terlalu berlebih. Batasan informasi dapat diwujud-kan dalam bentuk subtema dari tema tu-lisan yang ditentukan.

Langkah yang dilakukan setelah menen-tukan batasan informasi sesuai dengan topik bahasan adalah mengevaluasi batasan infor-masi yang telah dibuat. Hal ini untuk me-lihat kesesuaian antara kebutuhan informasi dengan batasan-batasan yang telah di-tentukan untuk menghindari kelebihan atau kekurangan informasi. Langkah ini tercer-min pada jawaban pertanyaan nomor empat yaitu "apakah Anda selalu mengevaluasi kembali batasan informasi yang telah Anda buat?". Tabel 1 menunjukkan bahwa se-bagian besar mahasiswa (58.9\%) kadang-kadang mengevaluasi batasan informasi yang telah dibuat. ACRL (2000) menya-takan bahwa kemampuan mengevaluasi jenis dan batas informasi yang diperlukan ditunjukkan dalam kegiatan membahas kem bali kebutuhan awal informasi untuk men-jelaskan, memperbaiki, atau menemukan kembali pertanyaan kemudian mendeskrip-sikan kriteria yang digunakan untuk mem-buat pilihan terhadap kebutuhan informasi.

Kemampuan mahasiswa menentukan sub-tema dalam suatu tulisan ilmiah yang telah ditentukan temanya merupakan wujud dari kemampuan menentukan batasan 
infor-masi yang diperlukan. Sub-tema yang me-wakili tema dengan baik akan mengarahkan mahasiswa dalam membatasi informasi-informasi apa saja yang seharusnya dicari. Hal ini tercermin pada pertanyaan nomor lima yaitu "jika pada suatu kesempatan, Anda diminta untuk membuat sebuah tu-lisan dengan tema Perkembangan Sistema-tika Invertebrata, maka sub-tema yang akan Anda pilih sebagai batasan permasalahan tersebut adalah?". Berdasarkan analisis ter-hadap jawaban mahasiswa, diketahui bahwa sebagian besar mahasiswa (78.2\%) memilih sub-tema karakteristik, klasifikasi, dan pe-ranan setiap phylum hewan Invertebrata. $15.4 \%$ memilih semua hal yang berhubu-ngan dengan hewan Invertebrata, 3.85\% memilih pembahasan mendalam mengenai klasifikasi pada setiap phylum, serta $2.56 \%$ memilih pembahasan setiap phylum hewan Invertebrata.

\section{KESIMPULAN}

Berdasarkan uraian hasil penelitian, analisis data, dan pembahasan yang diuraikan sebelumnya, maka dapat ditarik kesimpulan. Kemampuan mahasiswa menentukan jenis dan batasan informasi yang diperlukan sudah cukup baik. Pada umumnya (94.9\%) mahasiswa telah mampu menentukan lang-kah yang dilakukan dalam mencari informasi. Mahasiswa telah mampu memilih bentukbentuk informasi yang dapat digunakan sebagai sumber referensi baik informasi tercetak (39.7\%), digital/ elektronik (17.9\%) maupun keduanya (42.3\%).

Pada umumnya mahasiswa masih jarang menentukan batasan informasi $(84.6 \%)$ hanya yang sesuai dengan topik batasan dan masih jarang mengevaluasi batasan infor-masi yang dibuat $(58.6 \%)$.

Literasi informasi merupakan kompetensi utama yang memang pada awalnya harus dimiliki terutama untuk mahasiswa atau orang-orang yang berkecimpung di dunia perpustakaan. Namun, seiring pesat-nya perkembangan informasi dan tuntutan kompetensi pendidikan tinggi, mahasiswa pendidikan Biologi seharusnya mengembangkan literasi informasinya karena tugas-tugas dan materi perkuliahan yang hampir seluruhnya menuntut kemandirian mahasiswa untuk mengeksplor kemampuannya menggali informasi.

Pengajar (dosen) dan institusi terkait diharapkan dapat memberikan dukungan kepada mahasiswa untuk mengembangkan literasi informasinya dengan cara mengevaluasi sistem perkuliahan yang telah diterapkan dan menjadi fasilitator dalam pengembangan karya mahasiswa.

\section{UCAPAN TERIMA KASIH}

Ucapan terimakasih disampaikan pada dekan Fakultas Keguruan dan Ilmu Pendi-dikan dan ketua program studi
Pendidikan Biologi Universitas Muhammadiyah Surakarta yang telah memberikan ijin dan mem-fasilitasi terlaksanya penelitian ini.

\section{DAFTAR PUSTAKA}

American Association of School Librarians (AASL) and Association for Educa-tional Communications and Technolo-gy (AECT). 1988. Information Power: Building Partnership for Learning. Chicago: American Library Associati-on.

Association of College \& Research Libra-ries (ACRL). (2000). Information Litera-cy Competency Standards for Higher Education. (Online), (www.ala.org/mgrps/divs/arcl/ standards/.pdf), diakses pada 15 September 2014.

Hadi, S. (1981). Metode Research. Yogyakarta: Yayasan Penelitian Fakultas Psikologi UGM.

Hasugian, J. (2006). Penelusuran Informasi Ilmiah secara Online: Perlakuan terha-dap Seorang Pencari Informasi sebagai Real User. Pustaka: Jurnal Studi Perpustakaan dan Informasi. 2(1): 1-13.

Iman, P. (2013). Studi Komparatif Penting-nya Literasi Informasi Bagi Mahasiswa. Visi Pustaka. 15(2): 80-88.

Kuhlthau, C.C., Maniotes, L.K., Caspary, A.K. (2007). Guided Inquiry: Learning in the $21^{\text {st }}$ Century. Westport Connecticut: Libraries Unlimited.

Nasution, L.F. (2009). Literasi Informasi Mahasiswa Program Studi Ilmu Perpustakaan (S1) Fakultas Sastra Universitas Sumatera Utara (Semester VII-T.A 2009/2010). Skripsi. Medan: Program Studi Perpustakaan dan Informasi Fakultas Sastra Universitas Sumatera Utara.

Perwati. (2010). Pengantar Ilmu Taksonomi. Bogor: IPB.

Prasetyawan, I.B. (2011). Keberaksaraan Informasi (Information Literacy) bagi SDM Pengelola Perpustakaan di Era Keterbukaan Informasi. Makalah. Disampaikan dalam Pelatihan Pengelola Perpustakaan di Lingkungan Kementerian Perindustrian, Hotel Park, Jakarta, 26-28 Mei 2011.

Resmini, N. (2012). Orasi dan Literasi dalam Pengajaran Bahasa. Bandung: UPI.

Reza, M.Y. (2013). Deskripsi Literasi Informasi pada Siswa SMA International Baccalaureate (IB) Program Diploma di Cita Hati Surabaya. Media LibriNet 2(2): 7-18.

Sugiyono. (2006). Metode Penelitian Administrasi. Edisi Revisi. Bandung: Alfabeta.

Supardi, A. (1979). Statistik. Bandung: Fakultas Tarbiyah IAIN Sunan Gunung Jati.

UNESCO. 2006. Understandings of Literacy. Education for All Global Monitoring Report. 